\author{
KALINA PIWOŃSKA \\ MICHALINA URBAŃSKA \\ ELIZA PILARSKA \\ MACIEJ MINISZEWSKI \\ JAKUB STANISZEWSKI \\ ŁUKASZ KRYSZAK
}

\section{Managing sustainable consumption of durable \\ goods - A systematic \\ literature review}

\section{Introduction}

Kalina Piwońska, M.A., Poznan University of Economics and Business, Student Scholarly Association of Sustainable Development Economics, Poland, ORCID: 0000-0002-5061-0996.

Michalina Urbańska, B.A., Poznan University of Economics and Business, Student Scholarly Association of Sustainable

Development Economics, Poland, ORCID: 0000-0002-0630-414X.

Eliza Pilarska

Poznan University of Economics and Business,

Student Scholarly Association of Sustainable

Development Economics,Poland,

ORCID: 0000-0003-2312-4586.

Maciej Miniszewski, B.A.,

Poznan University of Economics and Business,

Student Scholarly Association of Sustainable

Development Economics,

Poland,

ORCID: 0000-0002-9731-2398.

Jakub Staniszewski, Ph.D.,

Poznan University of Economics and Business,

Department of Macroeconomics and Agricultural

Economics, Poland,

ORCID: 0000-0001-8074-0911.

Łukasz Kryszak, Ph.D., Poznan University of Economics and Business, Department of Macroeconomics and Agricultural Economics, Poland, ORCID: 0000-0001-8660-9236.
The production and use of durable goods have serious consequences for the natural environment. For example, the fashion industry produces over 92 million tonnes of waste per year and consumes 79 trillion litres of water (Niinimäki et al. 2020). It is estimated that clothing is responsible for $3 \%$ to $6.7 \%$ of human-caused $\mathrm{CO}_{2}$ emissions (Laitala et al. 2018). But the durable goods sector is composed of other sub-sectors, such as household appliances, furniture and electronic devices. The latter contain toxic materials, including lead, cadmium, mercury, etc. (Nixon et al. 2018). In this context, there is a need to promote the purchase and use of more eco-friendly substitutes, which have a lower impact on the environment. This will only be possible if consumers' preferences and behaviours are well recognised. A crucial factor is their willingness to pay (WTP), which is defined as the maximum price at or below which a consumer will definitely buy one unit of a product (Varian, 1992). However, in the 
context of environmental economics, it is usually associated with a price premium for green features of goods (e.g. Pommeranz and Steininger, 2020; Zhang et al. 2016), that is, how much more the consumer is ready to pay for products with ecological credentials in comparison to their traditional counterparts.

This raises the question of consumers' level of WTP for a given product and what are the factors that have an impact on consumers' WTP? Furthermore, these factors may differ between different countries, depending on whether the country is high income or low/middle income. We assume that environmental awareness is higher in more developed countries and so is the average WTP. The WTP may be stimulated by the characteristics of consumers but also by policy incentives. However, the question of whether these incentives are successful remains open.

The ambiguity of the WTP measurement, its determinants and policy impact in the context of durable goods is a premise for an in-depth literature review. There are few literature review techniques (cf. Maditati et al. 2018), but in this study, we employ a manual content analysis based on a sample of 47 documents from the SCOPUS database. In this paper, we aim to answer the following questions: (1) What are the main determinants of WTP for sustainable durable goods? (2) What are the main policy measures that influence WTP and do they have a significant impact on it? (3) What are the main contributions of authors dealing with the topic of sustainable consumption? We contribute to the literature by providing a comprehensive picture of recent studies regarding the issue of sustainable durable goods consumption in different parts of the world, and also by structuring the future research agenda in the field. The originality of this analysis is that we show not only the authors' contributions, but also systematize the determinants of willingness to pay for eco-products and the underlying policy implications.

The rest of the article is organised as follows. In the next section, we describe the methodology of our review and provide some descriptive statistics of the sample. In the subsequent section, we present the results of our review, which is divided into four parts: WTP determinants, policy measures and their impact, recent developments in the field (authors' contributions) and future research agenda. The final section provides some conclusions.

\section{Data and methods}

To conduct the review, SCOPUS database resources were used. We have chosen this particular database as it covers sources of proven quality and its 
coverage maybe wider than Web of Science. On the other hand, the use of Google Scholar could produce more results but it would also contain documents of a local importance and the quality of these works may be questionable. The main goal of the systematic literature review was to identify articles on the topic of willingness to pay for sustainable consumption. A query was generated on 03.11.2020 based on the following search: (TITLE-ABS-KEY (willingness AND to AND pay) OR TITLE-ABS-KEY (willingness-to-pay)) AND (TITLE-ABS-KEY (sustainable AND consumption) OR TITLE-ABS-KEY (bio) OR TITLE-ABS-KEY (green)). We did not specify any specific period of analysis which means that all indexed documents which fulfilled the constraints above were considered. SCOPUS initially returned 886 records. After preliminary screening of abstracts for further analysis, 733 papers remained valid. These works were further clustered according to the type of goods discussed. The results of this clustering are presented in figure 1 . They lead to the conclusion that the issue of willingness to pay for durable goods is well recognised in the literature but not yet intensively explored.

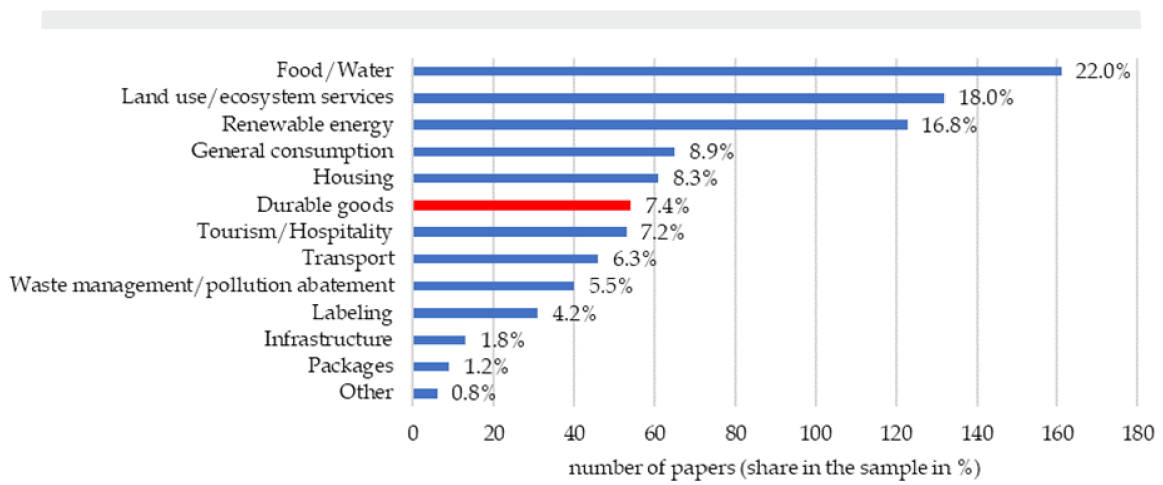

*Sample shares do not total $100 \%$ because some of the papers covered more than one topic.

Figure 1. Scope of sustainable consumption willingness-to-pay (WTP) evaluation

Source: own study, based on SCOPUS database results [accessed: 03.11.2020]

The content analysis was conducted on a sample of 46 out of 49 papers regarding durable goods (three documents were unavailable). Further classification of the articles is presented in figure 2. 


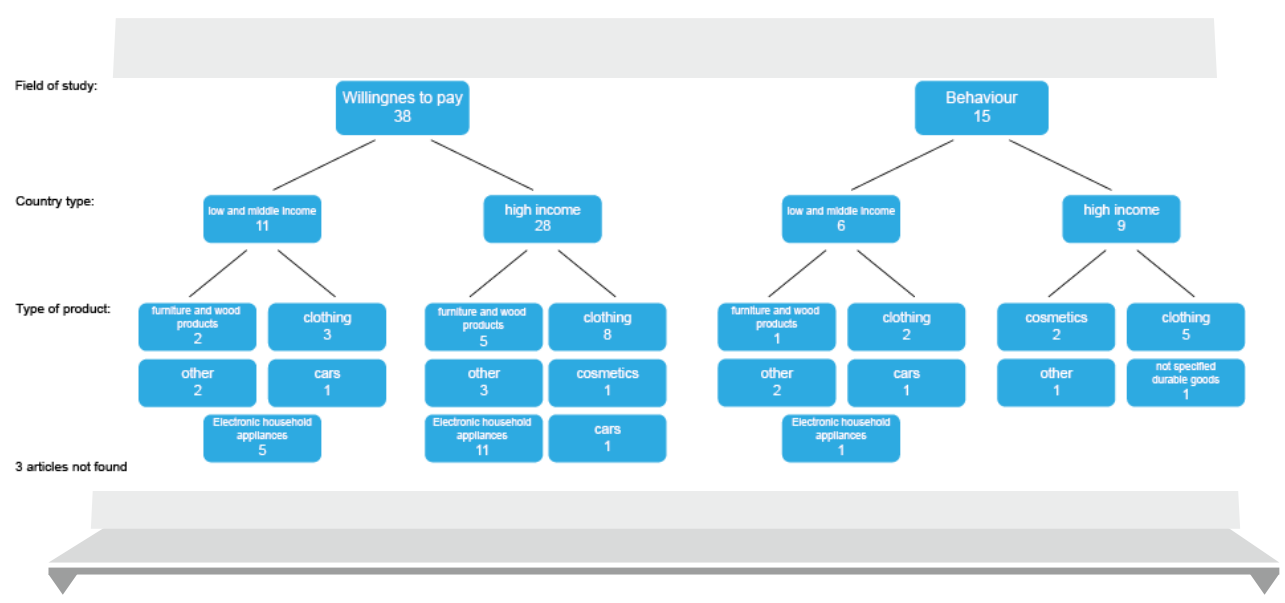

Figure 2. Classification of articles used for literature review

Source: own study, based on literature review

The two main subjects present in the literature involve customers' hypothetical willingness to pay more for eco-products and customers' actual behaviour, that is, paying more for eco-products. Sometimes both issues appear in one article. There are 38 documents that include the problem of customers' WTP and 15 papers dealing with customers' actual behaviour. Countries where the surveys were carried out were split into two groups: low/middle income and high income. In total, there were results from 25 countries: Italy, India, USA, Czech Republic, China, Germany, Japan, Sweden, Turkey, Kazakhstan, Taiwan, Thailand, France, Netherlands, South Korea, Malaysia, Brazil, Canada, Poland, Lithuania, Indonesia, UK, Slovenia, Romania, and Norway. Customers' WTP was analysed 11 times in 9 low/middle income countries and 28 times in 16 high-income countries. Customers' behaviour was analysed 6 times in 4 low/ middle income countries and 9 times in 7 high-income countries. This shows that the issue of sustainable durable goods is much wider explored in developed countries.

The durable goods analysed in the studies could be divided into 6 groups: furniture and wood products, cosmetics, clothing, electronic household appliances, cars and other. Some studies address more than one product or more than one category. The most frequently analysed groups were clothing and electronic household appliances. The WTP for the former was analysed 
in 3 articles on low/middle income countries and in 8 articles on high-income countries, while the latter were under consideration in 5 papers for low/middle income countries and as many as 11 in high-income countries. When it comes to actual behaviour, studies on clothes were the most frequent. The clothing sector was analysed in 7 out of 15 papers. Another category that was relatively popular was furniture and wood products. These were analysed in 7 out of 38 papers that considered WTP and in one paper that dealt with actual consumer behaviour.

The 'other' group consists of batteries, ophthalmic lenses, laundry detergents, plants in biodegradable pots, green investments and unspecified goods. When it comes to customer WTP research in low/middle income countries, ophthalmic lenses and green investment were analysed. In high-income countries, batteries, laundry detergents and other, unspecified goods were analysed.

Most of the studies were carried out in high-income countries and concern customers' willingness to pay for green products. It is relatively easier to research WTP than actual behaviour. This is because to do so only requires carrying out surveys. To explore actual behaviour, more data are needed. It is also necessary to make a comparison of customers' behaviour related to non-eco-products and eco-products in the same situation (ceteris paribus).

In high-income countries, there are more opportunities to do the research because a higher income leads to higher consumption, including durable goods. What is more, consumers in high-income countries have more financial resources, so they are more capable of spending it on green products. People in high-income countries are also more aware of environmental challenges.

\section{Results}

Determinants. Based on the identified group of papers, it is possible to map potential determinants of sustainable consumption. We found that only one paper in our sample did not cover the issue of determinants. A summary of the factors analysed in the rest of the papers is presented in figure 3 . We were able to identify at least a few research patterns. First, researchers most often referred to basic socio-economic and socio-demographic features. They seemed to be requirements in any research based on surveys. Second, we distinguished three main groups of factors. Two of them refer to the consumers and describe them based on either objective features or their subjective perception. Interestingly, some factors, like consumer knowledge, could be introduced in the research based on objective information such as years of education, as well as subjective self-declaration. The third set of factors referred to the features of the analysed

71

KALINA PIWOŃSKA

MICHALINA URBAŃSKA,

ELIZA PILARSKA

MACIEJ MINISZEWSKI,

JAKUB STANISZEWSKI.

ŁUKASZ KRYSZAK 
durable goods. Third, we identified the most common set of determinants. Despite the previously mentioned socio-demographic and socio-economic factors, researchers often analysed the impact of involvement in green activism (i.e. environmental organisations' participation). When it comes to consumer perception, influences in their social environment (subjective norms) were frequently taken into account, as well as environmental awareness and concern, which were often evaluated with questions on a Likert scale. Also, previous experience and knowledge, evaluated in a similar way, were often considered. The most commonly analysed product features were brand, price and durability/ quality. Under the category 'specific feature', we found characteristics of certain goods, for example, the type of wood in furniture. Products were most often assumed to be sustainable when they had any sort of eco-label or when the producing company was known for corporate social responsibility (CSR).

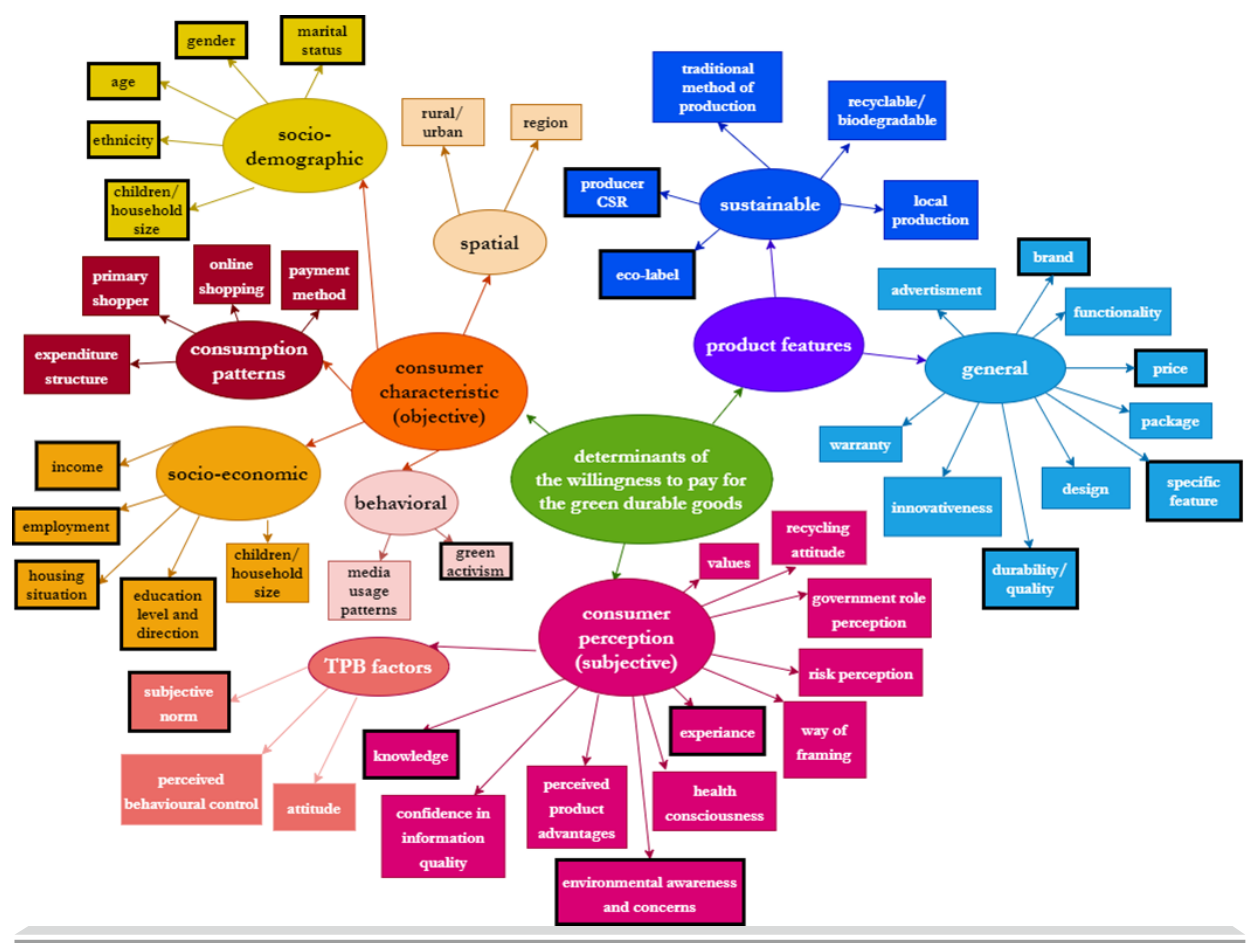

Figure 3. Determinants of willingness to pay for green durable goods * TPB stands for the theory of planned behaviour

Source: own study, based on literature review 
Finally, it is worth distinguishing some of the promising directions for future studies of WTP determinants in green durable goods consumption. Interesting and not well recognised is the impact of consumption patterns, such as online vs. in-person shopping (Choi et al. 2020). Furthermore, the impact of how the information about the green characteristics of a product is presented ("framed") may be a significant factor in encouraging consumption (Ramirez et al. 2015; Bull 2012).

Contributions. In the next step of the research, we decided to split the analysed articles into several groups in order to perform the analysis on their contributions. Issues connected with the confirmation of previous conclusions were of the greatest interest. Over $67 \%$ of the research papers underlined their contribution as confirming either earlier theories or previously used determinants or confirmed relations, which were already known or revealed in previous articles. For example, Shahsavar et al. (2020) confirmed that marital status influences WTP. Tuna and Tiyarattanachai (2019) proved that there is a relationship between green awareness and willingness to pay more for green products. Milovantseva (2016) claimed that environmental education can impact public support for implementation policies aimed at greening production and consumption.

Three articles emphasise the novelty of their contribution. The first one (Sandra and Alessandro, 2021) was a preliminary study of WTP for a new eco-friendly product that is still not available, and the authors used a relatively large sample of consumers for their research in comparison with the rest of the papers. In the second article (Lobasenko and Llerena, 2017), researchers used a new methodthe calibrated auction-conjoint method-which gives a clearer image of how customer preferences are formed. The authors argue that it is impossible to identify one crucial attribute of a product that has a greater impact on consumer preferences than other attributes. The last article that highlighted its novelty was by Veisten and Solberg (2004), who claim that theirs is the first study on market segmentation focusing on eco-labelled wood products in European countries. Another added value of the article is a downward adjustment of uncertain ecolabel choices and, accordingly, estimated WTP.

The next group consists of several articles that reveal their contribution as issues connected with geographical localisation in its broadest sense. One of them enhances existing knowledge in the field of green apparel consumption in a developing nation (Kumar et al. 2021). Another study (Huang et al. 2006), conducted at the local environment level, reveals that due to an increasing local economy and rising standards of living, local residents have a strong will to get 
involved in environmental protection. In another article, Potoglou et al. (2020) reveal cross-national differences in consumer knowledge, preferences and WTP, and, simultaneously, the authors claim that most respondents had limited knowledge or interest in product sustainability and, consistent with this, their choices were not strongly associated with ethical or climate-neutral conventional or organic materials. On the other hand, Sakagami, Okuda and Lim (2014) claim that there is no difference between Malaysian and Japanese customers. The authors indicate that consumers prefer REDD+ (Reducing Emissions from Deforestation and Forest Degradation)-certified products and are willing to pay a premium for them in both Japan and Malaysia.

We identified certification as a further category of contributions from the selected studies. Nearly $25 \%$ of the selected articles referred to matters connected with policy, certification or, more broadly, overall public relations and CSR issues. For example, Lee and Chen (2019) argue that green transparency not only has a significantly positive influence on CSR image and brand image but eventually positively influences green brand trust and green brand equity, and those constructs in turn positively affect the WTP for green cosmetics. Moreover, eco-certification is related to a higher WTP in a number of refurbished consumer product categories (Harms and Linton, 2016). The significant role of the recognisability of ecological and social labels in purchasing sustainable apparel has been underlined by Koszewska (2016). This recognisability directly contributes to the decision to buy a sustainable product and makes the consumer more willing to pay a premium for it. As Žurga and Tavčer (2014) claim in their article, the popularisation of eco-labels, more transparent and coherent labelling systems as well as the regulation of words such as 'green' and 'bio' may increase consumer willingness to choose more sustainable alternatives and consequently pay more for sustainable products. Thompson et al.'s (2010) study revealed useful marketing insights by using positive consumer reactions to eco-labelled products as an indicator of green consumerism. Finally, Lee (2011) claims that it might be effective to emphasise environmental issues and teach the importance of environmentally friendly consumer behaviour to fashion involved groups of consumers.

The final category of contributions worth distinguishing relates to financial issues. These issues are referred to in only $10 \%$ of the researched articles. Saphores et al. (2007) argue that consumers expect manufacturers to innovate to make their products more environmentally friendly without significantly increasing their prices. Tatavarthy and Mukherjee (2019) find that individuals who financed their durable goods purchases using loans expressed their 
intention to replace the goods after a longer period than those who financed their durable goods with a cash down payment. Finally, consumers place higher value on eco-labelled products than on non-eco-labelled products. As Min et al. (2017) claim, the provision of eco-labelled LED TVs should be encouraged when the total value of the product, defined as the sum of the price of non-eco-labelled LED TVs and the premium for an eco-labelled LED TV, outweighs the cost. If it is not profitable, there should be a government policy (tax refund or subsidy). Ecolabel education and promotion to the public has a significant positive impact, which has already been proven in most of the contributions of previous research articles.

Policy measures and their impact. In the next step, we reviewed the articles for policy measures and policy impacts to analyse governments' actions on maintaining sustainable products. Assumedly, policy measures are instruments of state intervention pointed out by the authors. In our sample, 20 articles evaluated policy measures. There are three main groups of policy measures: labelling and certification, subsidising and other.

The first group, labelling and certification, is the most common among the reviewed articles. This type of intervention yields the highest impact on policy. Half of the articles indicate labelling as statistically significant. Labelling, otherwise called eco-labelling or certification, identifies products proven to be environmentally preferable within a specific category. Both government and private labelling could positively impact consumers' WTF. Spinazze and Kant (1999) show that buyers of wooden products are willing to pay a $10 \%$ premium for nearly all certificated products. The same willingness to pay a premium is found in a survey on clothing conducted by Žurga and Tavčer (2014). Ghozali and Kaneko (2016) show that there is a greater WTP for government labelling (\$378 USD) than private labelling (\$163 USD) when buying air conditioning.

Žurga and Tavčer (2014) reported that insufficient knowledge of labelling is a major issue, and consumers tend not to fully understand labels and certificates. They suggest that not only is there a need for labelling, there is also a need for education and marketing. Bull (2012) found that providing information about running costs or running emissions of products is more explicit than labelling. It incentivises respondents towards more expensive and efficient products.

The second group includes subsidies as a form of state intervention. Choi et al. (2020) recommended targeted subsidies to foster a resilient and sustainable bio-based economy. When analysing the WTP of laundry detergents, Jo and Shin (2017) identified the need for policies that reduce the value-action gap. 
The third group-'other'-is the most varied and includes education, waste management and policy strategy. As a background for analysis, some authors indicated the EU Bioeconomy Strategy (Sandra and Alessandro, 2021) and Agenda 21, a 1992 United Nations conference on the environment and development (Thompson et al. 2010). Other policies suggested by various authors included extending the producers' responsibilities. Electronic waste management policies, low recycling rates and limitations on infrastructure for electronic waste should be implemented (Goswami 2008; Saphores et al. 2007; Nixon et al. 2006). To better manage the amount of waste, authorities ought to establish and implement a reuse-and-recycle system (Huang et al. 2006). Some authors also pointed out that an environmental education policy could raise public environmental awareness. Information campaigns and marketing may have a positive impact on WTP (Choi et al. 2020; Goswami, 2008; Saphores et al. 2007).

It should be noted that the authors of the selected studies usually outlined policy measures in the form of future recommendations. Interventions were not the main part of the reviewed articles. The results of WTP research have political implications, and some of the authors concluded by referring to instruments of state intervention. Only a few authors tried to determine whether a policy has a statistically significant impact on consumer behaviour. Some suggested policies were expressed in the form of the authors' opinion.

\section{Future research gaps}

In the 46 articles we examined, it was possible to find information about research limitations and suggestions to expand them in the future. In this part of the paper, we collated and grouped all of these to highlight areas that may appear to be relevant for continuing research in the field of sustainable consumption. We identified four main sets of future research gaps concerning the focus on specific factors, the model selection, the sample size and the application of knowledge in practice. We present them in table 1.

Table 1. Summary of future research gaps

\begin{tabular}{l|c|c}
\hline Group & Description & Frequency \\
\hline Focus & $\begin{array}{c}\text { Selection of other factors, attributes to analyse; a different/changed area of } \\
\text { study (adding a new context for the analysis) }\end{array}$ & 24 \\
\hline
\end{tabular}




\begin{tabular}{l|c|c}
\hline Sample & $\begin{array}{c}\text { Including other countries, products in the studies; selection of a more } \\
\text { representative sample (extending the analysis) }\end{array}$ & 13 \\
\hline Model & Selection of a different or extended model & 11 \\
\hline Practice & Application of the knowledge in the practice & 5 \\
\hline
\end{tabular}

Source: own study, based on literature review

The first group applies to more than half of the reviewed articles (51\%). Most authors suggest focusing on additional areas relative to their research, that is, adding a new context for the analysis. Cowan and Kinley (2014), Dodds et al. (2016) and Kumar et al. (2021) note that subsequent research should be based directly on consumer behaviour rather than on intention. On the other hand, most reviewed articles encourage expanding the group of factors studied. For example, different dimensions of materials could be represented by different attributes instead of a single one (Potoglou, 2020). In some studies, authors recommend not only considering additional factors but also digging deeper into their research. Geiger and Keller (2018) write about studies on the compassion effect on sustainable behaviour and the need to consider a more powerful manipulation of state compassion in the future.

The second group consists of suggestions about expanding sample size to get more representative data. This suggestion is found in more than a quarter of the studies (28\%). It is mainly based on collecting more data and doing research on more factors. In most cases, the added value would be to expand the study to other countries. Authors also propose adding more products (Michaud et al., 2017; De Medeiros et al., 2016) or firms (Casadesus-Masanell, 2009) to their studies.

In the third group, proposals for improving the models that were used are highlighted. This was found in nearly a quarter (23\%) of the articles. Xu et al. (2020) find that the extension model of the theory of planned behaviour (TPB) could improve the explained variance. The value of the analysis can be increased by extending theoretical consumption models to include elements aimed at sustainable consumption. This is suggested by, among others, Koszewska (2016), who suggests that consumption barriers could be reduced by introducing sustainable production guidelines.

The fourth group consists of the different approaches to the application of knowledge in practice. In several studies, it was an incentive to use research to build real strategies for business and public policy (Huang et al. 2006; Gupta 
and Singh, 2018; Tatavarthy and Mukherjee, 2019; Tuna and Tiyarattanachai, 2019). This is the smallest group listed, but it includes important and concrete proposals for translating knowledge gained in research into the promotion and development of sustainable consumption.

It is worth noting that authors usually suggested more than one solution from different groups, and sometimes the proposals covered issues related to more than one group. An example of this is the introduction of cross-variables into the model, which could be assigned to both the 'model' and 'sample' groups.

\section{Conclusions}

In this paper, we presented the results of an extensive literature review on sustainable goods consumption. More specifically, we were interested in factors that may influence consumers' WTP for 'green' products and their actual consumption behaviour. We also tried to organise the knowledge about policy impacts on the promotion of eco-friendly consumption. Finally, we aimed to collect future research directions on the topic. In our review, we used 46 papers indexed in the SCOPUS database.

We found that research on sustainable consumption is carried out much more often in high-income countries, while research in low/middle income countries is underrepresented. The authors of the selected articles use several groups of factors when they study WTP or consumer behaviour. These factors include consumers' socio-economic and demographic characteristics, product features and subjective perception. It was generally proven in many papers that subjectively expressed environmental awareness correlates with eco-friendly declarations and actual behaviour. Interestingly, not only are the true green characteristics of a product important, but the way they are presented may also impact consumer behaviours. This is especially important because it turns out that direct information about emissions is more effective than eco-labelling.

There are several ways the research on sustainable goods consumption can be expanded. However, it seems that at least two lines of enquiry may be particularly fruitful. First, research that concentrates on actual consumer behaviour is still underrepresented. This type of analysis requires obtaining detailed data on transactions, but it has a big advantage because it shows real processes rather than only declarations. The latter may be biased by the desire of respondents to appear more favourably. Underrepresentation of studies on actual behaviour may be also seen as a limitation of this review study. The sample is still relatively low so the general trends in literature are still emerging. Second, research that 
focuses more on the application of knowledge in practice (including policy practice) would be very useful. Obviously, another way of expanding the field is to do research similar to the previous analyses but that focusses on different products or is conducted on different groups of respondents.

\section{Summary}

Managing sustainable consumption of durable goods A systematic literature review

The production and use of durable goods have severe consequences for the natural environment. Reducing those influences is highly desirable and is possible to achieve by changing customers' preferences and promoting the purchase and usage of more green or eco-friendly substitutes. In this paper, we aimed to answer the following questions: (1) What are the main determinants of WTP for sustainable durable goods? (2) What are the main policy measures that influence WTP, and do they have a significant impact on it? (3) What are the main contributions of authors dealing with the topic of sustainable consumption? A manual content analysis was conducted, based on a sample of papers downloaded from the SCOPUS database that address the issue of willingness to pay for sustainable durable goods. Our analyses revealed that the socioeconomic characteristics of consumers have a significant impact on their WTP. Additionally, it has been proven that subjectively expressed environmental awareness correlates with eco-friendly declarations and actual behaviour. The most common policy measures to promote sustainable products were labelling and certification. There is significant room for further research by adding new contexts to previous analyses and also by looking for possibilities to transfer theoretical knowledge into business practice.

Keywords: durable goods, sustainable development, natural environment, willingness to pay, price premium.

\section{Streszczenie}

Zarządzanie zrównoważoną konsumpcją dóbr trwałego użytku - systematyczny przegląd literatury

Produkcja i użytkowanie dóbr trwałych powoduje poważne konsekwencje dla środowiska naturalnego. Ograniczenie tych 
oddziaływań jest bardzo pożądane i możliwe do osiągnięcia poprzez zmianę preferencji klientów oraz promowanie zakupu i użytkowania bardziej ekologicznych lub przyjaznych środowisku substytutów. W niniejszym opracowaniu staramy się odpowiedzieć na następujące pytania: (1) Jakie są główne determinanty gotowości do płacenia (WTP) za zrównoważone dobra trwałego użytku? (2) Jakie są główne środki polityki, które wpływają na WTP i czy mają one na nią znaczący wpływ? (3) Jaki jest główny wkład autorów zajmujących się tematem zrównoważonej konsumpcji? Przeprowadzono ręczną analizę treści na podstawie próby prac pobranych z bazy SCOPUS, które dotykają kwestii skłonności do płacenia za zrównoważone dobra trwałego użytku. Nasze analizy wykazały, że cechy społecznoekonomiczne konsumentów mają istotny wpływ na ich WTP. Dodatkowo udowodniono, że subiektywnie wyrażana świadomość ekologiczna koreluje z deklaracjami i faktycznymi zachowaniami proekologicznymi. Najczęstszym środkiem polityki promującym zrównoważone produkty było etykietowanie i certyfikacja. Istnieje duża przestrzeń do dalszych badań poprzez dodanie nowego kontekstu do wcześniejszych analiz, ale także poprzez poszukiwanie możliwości przeniesienia wiedzy teoretycznej do praktyki gospodarczej.

\section{Słowa}

kluczowe: dobra trwałego użytku, zrównoważony rozwój, środowisko naturalne, gotowość do zapłaty, premia cenowa.

JEL

classification: L67, L68, Q53.

\section{References}

Bull, J. (2012). Loads of green washing-can behavioural economics increase willingness-to-pay for efficient washing machines in the UK? Energy Policy, No. 50, pp. 242-252. https://doi.org/10.1016/j. enpol.2012.07.001

Casadesus-Masanell R., Crooke M., Reinhardt F., Vasishth V. (2009). Households' Willingness to pay for "green" goods: Evidence from Patagonia's introduction of organic cotton sportswear. Journal of 
Economics and Management Strategy, No. 18(1), pp. 203-233. DOI: https:/ doi.org/10.1111/j.1530-9134.2009.00212.x

Choi, Y., Chen, K., Marsh, T. L. (2020). Consumer preference for bio-based batteries. Journal of Consumer Behaviour, No. 19(4), pp. 382-396. DOI: https://doi.org/10.1002/cb.1827

Cowan, K., Kinley, T. (2014). Green spirit: Consumer empathies for green apparel. International Journal of Consumer Studies, No. 38(5), pp. 493-499. DOI: https://doi.org/10.1111/ijcs.12125

De Medeiros J.F., Ribeiro J.L.D., Cortimiglia M.N. (2016). Influence of perceived value on purchasing decisions of green products in Brazil. Journal of Cleaner Production, No. 110, pp. 158-169. DOI: https:/doi. org/10.1016/j.jclepro.2015.07.100

Dodds R., Pitts R.E., Smith W.W. (2016). Willingness to pay for environmentally linked clothing at an event: Visibility, environmental certification, and level of environmental concern. Tourism Recreation Research, No. 41(3), pp. 283-290. DOI: https:/doi.org/10.1080/02508281.2 016.1196029

Geiger S.M., Keller J. (2018). Shopping for Clothes and Sensitivity to the Suffering of Others: The Role of Compassion and Values in Sustainable Fashion Consumption. Environment and Behavior, No. 50(10), pp. 11191144. DOI: https:/ doi.org/10.1177/0013916517732109

Ghozali, A., Kaneko, S. (2016). Consumer Behavior and Ecolabeling. In: Kaneko S., Kawanishi M. (Eds) Climate Change Policies and Challenges in Indonesia (pp. 219-242). Tokyo: Springer. DOI: https://doi.org/10.1007/978-4-43155994-8_10

Goswami, P. (2008). Is the urban Indian consumer ready for environmentfriendly apparel? International Journal of Green Economics, No. 2(4), pp. 411426. DOI: https:/ / doi.org/10.1504/ijge.2008.022450

Gupta A., Singh U. (2018). Factors influencing environmentally responsive consumption behavior in India. SCMS Journal of Indian Management, No. 15(2), pp. 87-104.

Haber, L.H. (2014). The role of formal and informal structures in shaping corporation's relational capital. Management, No. 1, pp. 14-25.

Harms, R., Linton, J. D. (2015). Willingness to Pay for Eco-Certified Refurbished Products: The Effects of Environmental Attitudes and Knowledge. Journal of Industrial Ecology, No. 20(4), pp. 893-904. DOI: 10.1111/jiec.12301

Huang P., Zhang X., Deng X. (2006). Survey and analysis of public environmental awareness and performance in Ningbo, China: a case study on household electrical and electronic equipment. Journal of Cleaner Production, No. 14(18), pp. 1635-1643. DOI: https:/doi.org/10.1016/j. jclepro.2006.02.006 
Huang, P., Zhang, X., Deng, X. (2006). Survey and analysis of public environmental awareness and performance in Ningbo, China: a case study on household electrical and electronic equipment. Journal of Cleaner Production, No. 14(18), pp. 1635-1643. DOI: 10.1016/j.jclepro.2006.02.006 Jo, M., Shin, J. (2017). Market strategy for promoting green consumption: Consumer preference and policy implications for laundry detergent. International Journal of Consumer Studies, No. 41(3), pp. 283-290. DOI: https://doi.org/10.1111/ijcs.12339

Koszewska M. (2016). Understanding consumer behavior in the sustainable clothing market: Model development and verification. In: Muthu, S.S., Gardetti, M.A. (eds.). Green Fashion. Series: Environmental Footprints and Eco-design of Products and Processes (pp. 43-94). Singapore: Springer DOI: https:/doi. org/10.1007/978-981-10-0111-6_3

Kumar A., Prakash G., Kumar G. (2021). Does environmentally responsible purchase intention matter for consumers? A predictive sustainable model developed through an empirical study. Journal of Retailing and Consumer Services, No. 58. DOI: https:/doi.org/10.1016/j.jretconser.2020.102270

Laitala, K., Klepp, I. G., Henry, B. (2018). Does use matter? Comparison of environmental impacts of clothing based on fiber type. Sustainability, No. 10(7), 2524. DOI: https://doi.org/10.3390/su10072524

Lee, S. (2011). Consumers' Value, Environmental Consciousness, and Willingness to Pay more toward Green-Apparel Products. Journal of Global Fashion Marketing, No. 2(3), pp. 161-169. DOI: 10.1080/20932685.2011.10593094

Lee, Y.-H., Chen, S.-L. (2019). Effect of Green Attributes Transparency on WTA for Green Cosmetics: Mediating Effects of CSR and Green Brand Concepts. Sustainability, No. 11(19), 5258. DOI: 10.3390/su11195258

Lobasenko, V., Llerena, D. (2017). Elicitation of willingness to pay for upgradeable products with calibrated auction-conjoint method. Journal of Environmental Planning and Management, No. 60(11), pp. 2036-2055. DOI: 10.1080/09640568.2016.1271776

Maditati, D.R., Munim, Z.H., Schramm, H.J., Kummer, S. (2018). A review of green supply chain management: From bibliometric analysis to a conceptual framework and future research directions. Resources, Conservation and Recycling, No. 139, pp. 150-162.

Michaud C., Joly I., Llerena D., Lobasenko V. (2017). Consumers' willingness to pay for sustainable and innovative products: A choice experiment with upgradeable products. International Journal of Sustainable Development, No. 20, pp. 8-32. DOI: https:/doi.org/10.1504/IJSD.2017.083493

Milovantseva, N. (2016). Are American households willing to pay a premium for greening consumption of Information and Communication Technologies? Journal of Cleaner Production, No. 127, pp. 282-288. DOI: 10.1016/j.jclepro.2016.04.001 
Min S.-H., Lim S.-Y., Yoo S.-H. (2017). Consumers'willingness to pay a premium for eco-labeled LED TVs in Korea: A contingent valuation study. Sustainability, No. 9(5). DOI: 10.3390/su9050814

Niinimäki, K., Peters, G., Dahlbo, H., Perry, P., Rissanen, T., Gwilt, A. (2020). The environmental price of fast fashion. Nature Reviews Earth $\mathcal{E}$ Environment, 1(4), pp. 189-200.

Nixon, H., Saphores, J.D., Ogunseitan, O.A., Lincoln, J.D., Shapiro, A.A. (2006, May). Californian Households - Willingness to Pay for Green PCs. Proceedings of the 2006 IEEE International Symposium on Electronics and the Environment, 2006. pp. 150-155. DOI: https://doi.org/10.1109/ isee.2006.1650052

Pommeranz, C., Steininger, B. I. (2020). What Drives the Premium for Energy-Efficient Apartments - Green Awareness or Purchasing Power? Journal of Real Estate Finance and Economics, No. 62, pp. 22-241. DOI: https://doi.org/10.1007/s11146-020-09755-8

Potoglou D., Whitmarsh L., Whittle C., Tsouros I., Haggar P., Persson T. (2020). To what extent do people value sustainable-resourced materials? A choice experiment with cars and mobile phones across six countries. Journal of Cleaner Production, No. 246. DOI: https:/doi.org/ 10.1016/j. jclepro.2019.118957

Ramirez, E., Jiménez, F.R., Gau, R. (2015). Concrete and abstract goals associated with the consumption of environmentally sustainable products. European Journal of Marketing, Vol. 49, No. 9/10, pp. 1645-1665. DOI: https:/ / doi.org/10.1108/EJM-08-2012-0483

Sakagami, M., Okuda, T., Lim., H.F. (2014). Estimating potential preferences for wood products sourced from forests that are managed using sustainable forest management schemes. International Forestry Review, No. 16(3), pp. 301-309. DOI: 10.1505/146554814812572494

Sandra, N., Alessandro, P. (2021). Consumers' preferences, attitudes and willingness to pay for bio-textile in wood fibers. Journal of Retailing and Consumer Services, No. 58, 102304. DOI: 10.1016/j.jretconser.2020.102304

Saphores, J.-D.M., Nixon, H., Ogunseitan, O.A., Shapiro, A.A. (2007). California households' willingness to pay for "green" electronics. Journal of Environmental Planning and Management, No. 50(1), pp. 113-133. DOI: 10.1080/09640560601048549

Shahsavar, T., Kubeš, V., Baran, D. (2019). Willingness to pay for ecofriendly furniture based on demographic factors. Journal of Cleaner Production, 119466. DOI: 10.1016/j.jclepro.2019.119466

Spinazze, M.C., Kant, S. (1999). Market potential for certified forest (wood) products in Ontario, Canada. The Forestry Chronicle, No. 75(1), pp. 39-48. DOI: https://doi.org/10.5558/tfc75039-1

Tatavarthy A.D., Mukherjee K. (2019). Payment methods and their effect on durable goods replacement. Journal of Consumer Marketing, No. 36(4), pp. 484-493. DOI: https:/doi.org/10.1108/JCM-11-2017-2435 
Tatavarthy A.D., Mukherjee K. (2019). Payment methods and their effect on durable goods replacement. Journal of Consumer Marketing, No. 36(4), pp. 484-493. DOI: https:/doi.org/10.1108/JCM-11-2017-2435

Thompson, D.W., Anderson, R.C., Hansen, E.N., Kahle, L.R. (2009). Green segmentation and environmental certification: insights from forest products. Business Strategy and the Environment No. 19(5), pp. 319-334. DOI: https://doi.org/10.1002/bse.647

Tuna N., Tiyarattanachai R. (2019). Consumer perspectives on premium price of ecologically friendly product: A case study of ophthalmic lens in Thailand. IOP Conference Series: Earth and Environmental Science, No. 265(1). DOI: https:/doi.org/10.1088/1755-1315/265/1/012013

Veisten K., Solberg B. (2002). Willingness to Pay for Certified Wooden Furniture: A Market Segment Analysis. Wood and Fiber Science, No. 36(1), pp. 40-55.

Xu X., Wang S., Yu Y. (2020). Consumer's intention to purchase green furniture: Do health consciousness and environmental awareness matter? Science of the Total Environment, No. 704. DOI: https:/doi.org/10.1016/j. scitotenv.2019.135275

Zhang, L., Sun, C., Liu, H., \& Zheng, S. (2016). The role of public information in increasing homebuyers' willingness-to-pay for green housing: Evidence from Beijing. Ecological Economics, No. 129, pp. 40-49. DOI: https://doi.org/10.1016/j.ecolecon.2016.05.010

Žurga Z., Forte Tavčer P. (2013). Green consumerism, recognition and consideration of eco labels at textile purchase. Tekstilec, No. 56(2), pp. 100110. DOI: 10.14502/Tekstilec2013.56.100-110

Žurga, Z., Forte Tavčer, P. (2014). Apparel Purchasing with Consideration of Eco-labels among Slovenian Consumers. Fibres and Textiles in Eastern Europe, No. 22(5), pp. 20-27. 